\title{
IDENTITY POLITICS WITHIN TRIBE IN VILLAGE GOVERNMENT'S HEAD ELECTION: A case study in Wederok Village, Malaka Regency, East Nusa Tenggara
}

\author{
Laila Alfirdaus \\ Fridus Bria $^{1}$ \\ ${ }^{1}$ Universitas Diponegoro, \\ Jl. Prof. Sudarto No.13, Tembalang, Semarang City, Central Java, Indonesia. \\ laila.alfirdaus@live.undip.ac.id
}

Submitted: September 27, 2019, Reviewed: March 04, 2020, Accepted: March 29, 2020

\begin{abstract}
This article discusses identity politics in the village head election level. Studies on identity politics so far are mostly focused on elections in a government system that is in a higher concentration than a village, as in legislature and presidential elections. Attention to a similar issue in the village level is less to exist, partly because the community is generally assumed to be homogeneous. Meanwhile, in the village level, people remain plural, moreover in villages that live outside Java, where the number of tribes within communities is many. This is not to mention newcomers from the other islands. Using a case study in the Election of Village Heads in Wederok Village, Weliman Sub-district, Malacca District, East Nusa Tenggara, this research found that identity politics in village government head election play crucial role as in the other elections, as legislature and regency head elections, even in the same tribe in the same village. This article is based on qualitative research with in-depth interviews as main data collection methods. The results showed that in the election of Wederok village head, people become divided into particular parts, mostly based on sub-tribe (kinship). The village head election involved candidates from the different tribal identities, despite the connection between them because of inter-tribe marriage. Tribe-based competition in the village head level in Wederok even led to further conflict, which needs for reconciliation.
\end{abstract}

Keywords: Identity Politics; ethnicity/ethnicity; village head election.

\begin{abstract}
ABSTRAK
Artikel ini mendiskusikan politik identitas di pemilihan kepala desa. Studi tentang politik identitas selama ini lebih banyak difokuskan pada pemilihan didalam sistem pemerintahan yang lebih tinggi hierarkinya daripada desa, seperti di pemilihan legislative di DPRD dan DRR RI, serta pemilihan presiden. Perhatian terhadap isu yang sama di level desa masih kurang sebagian disebabkan karena desa umumnya diasumsikan secara sosial bersifat homogen. Padahal, di pedesaan, masyarakat tetap saja plural, terlebih untuk desa-esa di luar Jawa, dimana jumlah kesukuan bisa sangat variative dalam satu desa, belum lagi jika ditambah dengan para pendatang dari luar pulau. Dengan menggunakan studi kasus, pemilihan kepala desa di desa Wederok, Kecamatan Weliman, Kabupaten Malaka, Nusa Tenggara Timur, penelitian ini menemukan bahwa identitas politik di pemilihan kepala desa sama kuatnya dengan politik identitas di pemilu legislatif dan pemilihan presiden. Tulisan ini didasarkan pada penelitian kualitatif dengan wawancara mendalam sebagai metode pnegumpulan data yang utama. Hasil dari penelitian ini menjelaskan bahwa pemilihan kepala desa telah menyebabkan keterbelahan di masyarakat menjadi beberapa bagian sebagian besar dikarenakan perbedaan kesukuan. Pemilihan kepala desa sendiri melibatkan kandidat dari identitas kesukuan yang berbeda, meskipun kedua kandidat ini sebenarnya terhubung satu sama lain melalui ikatan pernikahan lintas suku. Tetapi, persaingan berbasis kesukuan di pemilihan kepala desa telah menyebabkan konflik yang lebih serius, dan memerlukan upaya-upaya rekonsiliasi.
\end{abstract}

Kata kunci: Politik Identitas; suku/etnis; pemilihan kepala desa. 
Vol..6, No.1, 2020

Doi: https://doi.org/10.24198/cosmogov.v6i1.23761

http://jurnal.unpad.ac.id/cosmogov/index

\section{BACKGROUND}

This article aims to examine the identity of politics in the election of the village head. The election of village head 2016 in Wederok Village brings up the unusual phenomenon, in which differences can still be exploited even within the same tribal group, which referring to Smith (1991) this explain identity development. While identity politics is mostly analyzed through ethnicity, religion, and ideology (Sjaf, 2014), in the case of Wederok it can happen even among the same tribe, but different families (clan/kinship). The Wederok experience has told us a lesson that identity politics can always be exploited even in micro-scope and landscape, which then further expand to different ethnicities, religious groups, and the other tribal groups

The issue of identity politics in Wederok is raised by a couple of village head candidates to attract sympathy and support from ethnic, religious, and ideological communities because people mostly view it as very strategic (Kivsto and Nefzger, 1993). The election of the village head in Wederok brought up the political identity, the issue of a native son. The nuance of the political character related to local interests in the problems of ethnicity, religion, ideology (Buchari, 2014), represented from each of them, the elite movement of regional expansion on development or regional development as topic political elites (Abbas, 2013).

This article confirms the argument that the election dynamics relate to identity politics (Fernandes, 2018, Sosiawan, 2015, Herdiansyah, 2017). While there have been an abundant number of studies about identity politics in legislature and regency government head or presidential election (Saputro, 2018, Santoso, 2019, Lestari, 2019, Fikri, 2018, and Hemay and Munandar, 2016), the similar discussion in village head elections is quite rare to find out.

In Indonesia, village is part of the most basic governance system. Their role is vital because the village government directly face the community, whether it is in the process of development or the process of applying policies brought up from the regency, provincial and central governments. However, village is not as static as we imagine. Moreover, if we trace further in village, in which the society is plural by identities, either because of tribes, ethnicities or other social attributes, as in some villages in East Nusa Tenggara that become the destination for transmigration and migration. The dynamics become more apparent, when it comes to village government head election processes. For the people, village head election is crucial because it is all about prestige and social status in community. Therefore, it is not surprising should people mobilize as much resource as they have, including identities, to gain votes in the election.

Tracing to Indonesian history, before the colonial government was coming in Indonesia, village was a place inhabited by a group of people or communities occupying the particular area. In that place, there was a person who was stronger or older among the groups or a group of people called "primus interpares." So hereditary, the system of leadership can be replaced by the person desired by the community, either through social contracts 
Vol..6, No.1, 2020

Doi: https://doi.org/10.24198/cosmogov.v6i1.23761

http://jurnal.unpad.ac.id/cosmogov/index

or through the other mechanisms. In the colonial era, it is under the leadership of Raffles, the village head election was started to introduce. It then continued after independence, Old Order, New Order, and reformation era.

While New Order had been so hegemonic including in setting up village head election, so it benefitted politically to the central government (read: Golkar - the government party), the reformation in 1998 brought a significant change to the political system; namely democratization, both in the economy and politics of Indonesian society. Democratization has brought the other changes, including the system of the general elections, which allow parties to participate within. Later, reformation was scrutinized for not bringing stronger democratization, but rather strengthening oligarchy, where government system is dominated by elite society (Hidayat, 2010). The rise of elite amidst the process of democratization in Jakarta and urban areas has a strong influence on the local village level in terms of hard competition in village head election that involve identity politics within, moreover with the experience of general elections in 2014 and Jakarta governor election in 2016, which exposed much the issues of identities.

Of course, elections and identity politics is not a new thing to discuss in political science studies. There have been some studies discussing this. Nyarwi's study (2008) in West Kalimantan, Bangka Belitung and South Sulawesi tried to reveal whether there is relationships between ethnicity and political behavior in elections. In Nyarwi's view, in the local leader election of West Kalimantan, ethnic identities play the critical rule. In the direct vote, society tends to choose the candidate who has the same ethnic identities with them. However, this did not happen in Bangka Belitung, and South Sulawesi, in which in both province ethnic sentiment can be said to be less happening. The very token of this is the fact that society can accept the leader who comes from different ethnic background with them.

In village level, things become more complicated, especially since the introduction of village fund policy, as a result of village law reform, as explained through Law No. 6/2014 on Village. The implementation of DAD (Dana Alokasi Desa or Village Fund Allocation), has made the position of per village head in society more strategic. The Decentralization of Village, through Law No. 6/2014 has opened up opportunities for villages to expand their autonomy. Holding power in village government thus is seen to be crucial for some people to have access to power.

Along with this, village head election becomes a more strategic area in village's power contestation. It is not a surprise, should we find some conflicts in village head elections in some local regions (Wance and Ibrahim, 2019).

This also what happens in Wederok, Malaka regency, East Nusa Tenggara. We found that conflict heightens especially since the introduction of Law No. 6/2014 involving people from different identity backgrounds. Village head election in Wederok poses a conflict between members of the society and raises mistrust for both candidates in the election. They are Anton as Oalen (Son-in-law) as a 
Vol..6, No.1, 2020

Doi: https://doi.org/10.24198/cosmogov.v6i1.23761

http://jurnal.unpad.ac.id/cosmogov/index

candidate and Lius as the native son who later won the election in Wederok. This study tries reveal how identity plays crucial role conflict related to village head election.

\section{METHOD}

This study applied qualitative methods and used case study as a research approach. Fieldwork was conducted during December 2018 to March 2019 in Wederok village, Malaka regency, East Nusa Tenggara. Data collection methods involve interviews and Forum Group Discussion (FGD) with more or less 20 informants from both candidates in village head election, tribal leaders, religious leaders and village citizens. Further, the researcher doing some observations as supporting data to scrutinize in detail the social conflict that exists in the society of Wederok related to village head election.

\section{RESULT AND DISCUSSION Identity Politics and (Village Head) Election}

As a fundamental concept, identity is together indeed become a character or symbol that we often hear. The identification also becomes a concept and has a deep meaning. Another name of political identity is biopolitical (Beyme, 2022) refers to politics based on biological origins, or political differences (Widayanti, 2009), which can be described as politics that is based on differences in social identities. Pluralities among Indonesian people has rised the concern on political identity. The identification of political identity in Indonesia, is more likely to be related with ethnicity, religion, ideology, and localities.
Indeed, we will find it easier to know and understand what identity is; for example, when we born, the gender; we can also identify them by their name or the status in the family.

Identity's classification has two different groups (Abdillah, 2012). The first is a social identity that consisting of class, race, ethnicity, gender, and sexuality. The second is Political identity that includes nationality and citizenship. Social status can be determined as a subpart of social interaction, while political identity is defined as part of the subject of community ownership and becomes the differentiator.

Political identity can simply determine an essential part of the subject of political community bonds. While the definition of political identity is the organizing political system, both social status and political identity, thus, simply identity can be interpreted as an essential character base in recognizing a thing. Personality is also a very high character for a person or community to be central to everyone to know the other group.

It can reflect the uniqueness of a person's personality and identity. It is most likely that the dominance of the person who has the same selfish nature will be one thing that desire of their purpose brought up the friction to win the power of the group. The author concluded that political identity is a similarity between a person and groups to reach some goals that related to their analogy such as, ethnicity, culture, religion, gender.

Dealing with this, Brubaker and Cooper (2000) remind us not to misunderstand identity as merely a social construction or something socially given. 
Vol..6, No.1, 2020

Doi: https://doi.org/10.24198/cosmogov.v6i1.23761 http://jurnal.unpad.ac.id/cosmogov/index

They rather suggest us to see identity, both as category of practice and as category of analysis. By category of practice, identity is used to explain everyday setting to explain who they are, what activities they do, and what make them differ from the others, which of course, can be related and elaborated as a means to build the sense of collective interests and collective action. In this, identity politics gets its clearer meaning.

Meanwhile, by category of analysis, identity is not perceived as something tangible and physically exists, but it is considered to be an instrument to identify social category to deepen the understanding of particular social phenomenon. Confirming Brubaker and Cooper, as what happen in Wederok are, identities and the practices of identity-based bothering, practically is not less than an instrument to create or generate or retain the status of being an elite (Brass, 2000).

It is not hard to find out elite deliberately blows up identity issues in political arena, as through the use of native son concept to win the election. Eindhoven (2007) emphasized that the reformation era in Indonesia brought the local elites to consolidate the force of identity (ethnicity), so they can refuse their rivalries, who comes from different ethnic background, in the name of ethnic dignity. This phenomenon is evident in the development of the new district, as well as the new villages, in which elite strive to consolidate their community using identity as an instrument to make their political goal achieved. In Indonesia, the revival of political identity is not solely a response to national political change, which was centralistic under New Order regime's control. Political identity also happened and was encouraged by the emergence of regional autonomy all over Indonesia (Haboddin, 2012)

The political identity was undoubtedly coloring the policy, autonomy, and democracy (Cheung, 1993, Maarif, 2012). In the change of political independence that influences the whole district in Indonesia, including the District of Malaka, especially Wederok Village, which has significant ethnic and tribal differences, the local political interests are very influential in it. Hence, ethnic issues have a great opportunity to be exploited in local politics.

Many local and national political actors are strengthening this issue intently for the sake of power division. Haboddin stated that political identity is more about the political view of the delegation, either political status or social identity as a political source.

Policy on decentralization and regional autonomy gives high power and authority to the people in the community to choose the regional head directly, apparently raises a phenomenon ao political identity. According to Haboddin (2012), "in fact, political identity at the local level occurred within decentralized politics."

In this case, the community that is plural by ethnicities and tribes becomes the main target to be influenced by the elites, so that ethnic issues can continue to be played and reproduced massively. The problems that are arising from the strengthening of ethnic issues and the sense of specific ethnic sentiment is basically about to win power contestation. 
Vol..6, No.1, 2020

Doi: https://doi.org/10.24198/cosmogov.v6i1.23761 http://jurnal.unpad.ac.id/cosmogov/index

So, the tension between different ethnicities in a region profoundly relates to political and economic areas, in which the feeling of being limited in terms of access, resources and policy in the village, together with the feeling of ethnic sentiment, are blown up and preserved by elites to maintain community's primordialist view. The same problem was also the case in the district of Malaka, especially in Wederok Village.

Identity politics becomes instrumental for collecting supports in elections and leads to ethnic identity politicization in every political period. In the village head election in Wederok, the indicator was an identity battle that always rests on ethnic background, tribe, and ethnicity.

Conflict and resistance that are often related to the inter-ethnic sentiments, as we knew, as in the struggle for the seats including in the village government, remains happen.

\section{Identity Politics and Village Head Election: The Case of Wederok, Malaka District}

Ethnic diversity in Indonesia is deemed to yield social advantage because of the differences, which can be exploited as an instrument to win the power contestation (Faturahman, 2018). The differences among ethnic in Indonesia is a characteristic that is made as a serious consideration election and policy making. This also what happens in Wederok's village head election.

In the village head election at Wederok in 2016, two candidates come from the same ethnic, namely Uma
Mamulak ethnic (Ikumuan) they are, Lius and Anton. Luis is a native son of Ikumuan, and Anton is the son in law of Ikumuan. This election brought pros and cons because the candidates come from the same clan; but it then led to a conflict among the people of Wederok, because of the issue of origins.

The result of the interview found that the glorification of ethnic issues in the village head election of Wederok, cannot be separated from the influence of Tua Nai and $\mathrm{Oa}$ Lae concept. This refers to native son and son-in-law. In Wederok, adopting the matrilineal system, the native son is deemed to have stronger influence than a son in law; which later raises the questions of identity politics. The following interview reveals how this issue has been a concern in Wederok society: ${ }^{1}$

"The matrilineal system nowadays has a shifting meaning, and in fact, our culture taught us that we have to respect our son in law, but for the sake of political interests, son in law who come from another ethnic group or tribal group cannot become the candidate of the village head. These issues have always been blown in the process of village head election."

According to the interviews, in matrilineal system of Wederok tribe, sonin-law actually is allowed to govern and administer the village. In fact, this law gets different interpretation that respect to sonin-law is in social areas. In terms of politics, it is native son that has a right to govern.

\footnotetext{
${ }^{1}$ SB, Wederok, December 2018.
} 
Vol..6, No.1, 2020

Doi: https://doi.org/10.24198/cosmogov.v6i1.23761 http://jurnal.unpad.ac.id/cosmogov/index

Related to the heightening intensity of identity politics issues, I found that these issues are always blew up in the ritual meeting, so people are expected to be aware of the importance of nativeness in politics. The following sentence from an interview with the legendary figure of Wederok confirms this: ${ }^{2}$

"Talking about the compulsion to choose the leader from the Ikumuan tribe, always we do in every event, either joy or sorrow. The purpose is to guide the society to choose the Ikumuan. There are two tensions between the common issues and the issue of the landlord. These two different things raised the polemic in village head election".

Based on the result of the interviews, we can conclude that the intensity of the identity politics issue in the village head election of Wederok related with two things, the culture and the landlord. Religion obliges to choose the $\mathrm{Oa}$ Lae; on the other side, they have to adapt to their son. Because of the tension, the intensity of the issue continues to justify and rationalize both of the problems.

Dealing with the first point mentioned above (cultural aspect), traditional belief of Wederok community asserts that for the purpose of preserving the tradition and respecting for the ancestors, the Oa Lae (native son) should be prioritized in social life, including in election.

However, society changes, community also develops. More people

${ }^{2}$ Interview on April 2019 come to the village and make the social life the village gets more dynamics. The interface with people from different has induced some changes in the later traditional values of the community, including in family relationships. While the traditional belief asserts that Oa Lae is the priority, later, people also think about equality and respectfulness to the new comers. Moreover, those people are also tied with inter-tribe marriage.

The changes, in fact, unavoidably influence other things including in terms of local politics. Not in familial relationships, and in social activities, new comers, which now become part of the family, also aspire for leading the village government.

Moreover, if the new comers are the landlord or the ones that have resources in the village and known to be among the rich, in this point, tension started to arise, not only between family members, but also between the people in the village. It is because, each candidate have masses that back them up in village head election. The tense situation even continued after the election done.

Some efforts to resolve the conflict has been made, even including the regency government. In the focused group discussion delivered by Mr. SR, and was reaffirmed by the customary leader, it is said that: ${ }^{3}$

"We should accept and forgive each other because the election is over and the leader also our people. So, we should make peace based on our tradition, not only formality like what we have done."

\footnotetext{
${ }^{3}$ Sr and KK, 13 January 2019 in Malaka district.
} 
Vol..6, No.1, 2020

Doi: https://doi.org/10.24198/cosmogov.v6i1.23761 http://jurnal.unpad.ac.id/cosmogov/index

Another cause of unfinished problem solving is a different perception, and the interests of both candidates as disclosed in the FGD by a public figure, who said: ${ }^{4}$

"There are political interests, so the development in this village did not run well; the government activities face constraints from intern-tribe conflict."

The leader of the teenagers' organization of the village explained that that conventional effort has been made but does not reach a final agreement. The following interview revealed:

"Conventional efforts are being implemented but does not reach the final deal, up to now. Also, every candidate has their interest, and this inhibits the effort of conflict resolution. An informal customary agreement relating to the pasture was also already made to minimize the conflict, but it remains no change, the conflict remains happening."

Based on the interviews, we can see that the conventional effort to reconcile the two groups post village head election had not completed. Due to the dominance of political interests, those who get involved in conflict still adopted the truth that they believe, and do not want to really build dialogues. Problem-solving, therefore, is only a formality.

Therefore, conflict resolution desired by the people of Wederok is to establish a traditional peace dialogue using social modality they owned. Resolution

${ }^{4}$ PO, 68 yo, 13 Januar 2019, malaka district. with cancellation is by eliminating the purpose of conflict. Dialogue and negotiation are crucial as a way-out. The dialogue and negotiations need to support peace building after the elections (Kiftiyah, 2019). The people expected that the elected village head, should involve their rivalries in the past village head election in village decision making, so tension can be lessened.

Now the democratic system based on traditions in Wederok can be said to be no longer relatable with the village head election. We can see the process of village head election, beginning from registration, campaigns, and political communication that always decompile the identity of certain tribes to influence the votes.

General election is one of the ways in the system of democracy for society to choose representatives and leaders of the community who will be seated in the policy making bodies. Because society cannot lead the government directly, so it is necessary to embrace the representative of an organization to rule a state for some time. The general election is also an essential means for the country that adheres to democracy, which gives a political opportunity for citizens to choose its representative and leaders who will respond to their aspirations.

Political identity in general elections, therefore can be said to erode the democracy's effectiveness. Although the voting was done democratically based on the principles of elections, but in practice people choose based on primordial identities rather than on the quality of vision and missions' of the candidates (Morowitz, 1998). 
Vol..6, No.1, 2020

Doi: https://doi.org/10.24198/cosmogov.v6i1.23761 http://jurnal.unpad.ac.id/cosmogov/index

The case in Wederok implies that identity politics, which tend to bring community into conflict is prone not only in higher level of elections, as Saputro (2018), Santoso (2019), Lestari (2019), Fikri (2018), and Hemay and Munandar (2016) used to see. It can happen even in lowest level of election as in village government head election. This told us that election is subject to contention, once it is not managed well. Therefore, awareness raising since in village level is crucial, so people can play more active role in making sure that the political processes is not featured with elite mobilization.

In the case of Wederok, interestingly, identity politics not happen necessarily across ethnic groups, as scholars usually portray (Fernandes, 2018, Sosiawan, 2015, Herdiansyah, 2017). It can even happen within family ties. In this case, it happens within the same tribal group, which was fragmented by different perception about the requirement to be community leaders. This confirms Smith (1991) that locus of identity development is not limited to different identity groups. Within the same group, people can draw borders, to make social differentitation for whatever motives. May it be politics and economy.

\section{CONCLUSSION}

Based on the description above, we can see that identity politics is inherent within electoral processes including in micro level as in village government head election. Based on case study in Wederok, East Nusa Tenggara Province, we can see that political identity also plays crucial role not only in legislature, presidential, governor or regency government head elections. It could make an account in village government head election.

Further, we can also see that identity politics within electoral processes not only exit across ethnicities, religious groups, local origins, and language differences. Within the same tribe and clan, differences can still be withdrawn, and identity politics is highlighted to be an instrument for winning the votes. This confirm Smith (1991) that asserts identities and identity politics develop in any context as much as they can.

In Wederok, it is commonly known that ethnic Ikumuan is the dominant one, because they have resources including some prominent figures, who are active in Wederok's social and political activities. There are some tribes that are influential in the establishment of Wederok, that ethnic always win the election and spread the issues about political identity, that caused the elected leader is less professional and competen.

\section{REFERENCES}

Abbas, Rusdi J. (2013). Demokrasi di Aras lokal: Praktik Politik Elit Lokal di Maluku Utara. Yogyakarta: Cerahmedia

Abdilah, Ubed S. (2002). Politik Identitas; Pergulatan Tanda Tanpa Identitas. Magelang: Indonesiatera

Ahmad, Nyarwi et.al., "Faktor Etnis dalam Pilkada?", dalam Kajian Bulanan Lingkaran Survei Indonesia, No 09, (Januari 2008), hlm. 1 .

Beyme, Klaus Von. (2002). Biopolitical Ideologies and their Impact on The New Social Movements, dalam Ubed Abdilah S, (2002). Politik Identitas; Pergulatan Tanda Tanpa 
Vol..6, No.1, 2020

Doi: https://doi.org/10.24198/cosmogov.v6i1.23761

http://jurnal.unpad.ac.id/cosmogov/index

Identitas. Indonesiatera, p. 44

Magelang:

Brass, Paul. (2000). Elite group, symbol manipulation and ethnic identity among the Moslems of South Asia. In John Hutchinson, Anthony D. Smith (eds), Nationalism: Critical concept in Political Science Volume III. London: Routledge

Brubaker, Rogers and Cooper, Frederick. (2000). "Beyond identity." Journal of Theory and Society, 29: 1-47.

Buchari, Sri Astuti. (2014). Kebangkitan Etnis Menuju Politik Identitas. Jakarta: Yayasan Obor Indonesia.

Cheung. Yuet W. (1993). "Approach to Ethnicity; Chelearing Roadblocks in the Study of Ethnicity and Substance Abuse." International Journal of Addictions, 28 (12), 1209-1226

Eindhoven, M.. (2007). New colonizers?: Identity, representation and government in the post-New Order Mentawai Archipelago. Amsterdam: Brill

Fernandes, Arya. (2018). Politik identitas dalam Pemilu 2019: Proyeksi dan efektivitas. CSIS Election Series No. 1. Jakarta: CSIS.

Fikri, Sirajudin. (2018). Politik Identitas dan dan penguatan Demokrasi Lokal (Kekuatan Wong kito dalam demokrasi lokal). Tamaddun: Jurnal Kebudayaan dan Sastra Islam, 18 (2): 167-181.

Haboddin, Muhtar. (2012). Menguatnya politik identitas di Ranah Lokal. Jurnal Pemerintahan 3 (1): 65-74.

Hemay, Idris and Munandar, Aris. (2016). Politik Identitas dan Pencitraan Kandidat Gubernur Terhadap Perilaku Pemilih. Politik: Jurnal Kajian Politik dan Masalah Pembangunan 12 (1): 1737-1748

Herdiansyah, Ari Ginanjar. (2017). Politik identitas dalam kompetisi pemilu di Indonesia pasca 2014. Jurnal Bawaslu 3 (2): 169-183.

Hidayat, Syarif. (2010), Demokrasi elitis? Relasi kekuasaan pasca Pilkada", Jurnal Masyarakat, Kebudayaan dan Politik, 23 (2), 169-180.
Kiftiyah, Anifatul. (2019). Reconciliation Efforts of Identity Politics Post Of Election 2019 in Indonesia. Jurnal Analisis Kebijakan 3 (1): 63-75.

Kivsto, P., Nefzger, B. (1993). Symbolic Ethnic and American Jews. The Relationship of Ethnic Identity to Behavior and Group Affiliation. Social Science Jurnal, 30: 1-12.

Lestari, D. (2019). Pilkada DKI Jakarta 2017: Dinamika Politik Identitas di Indonesia. JUPE: Jurnal Pendidikan Mandala 4 (4): 12-16.

Maarif, Ahmad Syafii. (2012). Politik Identitas dan Masa Depan Pluralisme Kita. Jakarta. Yayasan Abad Demokrasi: Jakarta

Morowitz, Donald L. (1998). Demokrasi pada Masyarakat Majemuk"'. Dalam Larry Diamond dan Mars F Plattner. Nasionalisme, Konflik Etnik dan Demokrasi Bandung: ITB Press.

Santoso, Eka Putra B. (2019). Pemilu dan Pilkada dalam Pusaran Politik Identitas. Resolusi: Jurnal Sosial Politik 2 (2): 150-155.

Saputro, Agus. (2018). Agama Dan Negara : Politik Identitas Menuju Pilpres 2019. Asketik: Jurnal Agama dan Perubahan Sosial, 2 (2): 111-120.

Sjaf, Sofyan. (2014). Politik Etnik: Dinamika Politik Lokal di Kendari. Jakarta: Yayasan Obor Indonesia.

Smith, Elsie. (1991). Ethnic Identity Development: Toward the Development of a Theory Within the Context of Majority/Minority Status." Journal of Councelling and Development 70 (1): 181-88.

Sosiawan, E. (2015). Representasi Politik identitas Dalam Kampanye Online Calon Legistatif Partai Politik Peserta Pemilu 2014. Jurnal Ilmu Komunikasi 15 (3): 234-248

Wance, Marno and Ibrahim, Abdul. (2019). Faktor Penyebab Konflik Pemilihan Kepala Desa Serentak di Kabupaten Halmahera Selatan. Journal of Governance and Local Politics, 1 (2): 157-174.

Widayanti, Titik. (2009). Politik subaltern: Pergaulan identitas waria. Yogyakarta: Research Center 
Vol..6, No.1, 2020

Doi: https://doi.org/10.24198/cosmogov.v6i1.23761

http://jurnal.unpad.ac.id/cosmogov/index

Politics and Government, Jurusan Politik dan Pemerintahan UGM.

Zerunisa, R., \& Winarni, F. (2017).

Political Marketing Kandidat

Dalam Pemilihan Kepala Desa
(Pilkades): Studi Kasus Desa Getan Kecamatan Gantiwarno Kabupaten Klaten. Jurnal Adinegara, 3 (2): 100-104. 